\title{
喉頭乳頭腫の臨床－HPV 感染とワクチン治療一
}

\author{
牧 山清·松 崎 洋 海·平井良 治 \\ Laryngeal Papilloma in Clinical Practice: Human Papillomavirus Infection \\ and Vaccine Treatment
}

\author{
Kiyoshi Makiyama, Hiroumi Matsuzaki and Ryoji Hirai
}

\begin{abstract}
With the exception of a few cases that become cancerous, laryngeal papilloma is fundamentally a benign disease. At the same time, however, it is also a refractory disease that causes very serious impairments in respiratory and phonatory functions. Human papillomavirus (HPV), a cause of these papillomas, infects not only the site of the tumor, but also the surrounding laryngeal mucosa. Thus, recurrent laryngeal papillomatosis (RLP) is both a neoplastic disease and an infectious disease.

HPV-DNA tests for various laryngeal diseases were performed to investigate whether there was HPV infection of the larynx. All patients with non-neoplastic diseases were negative for HPV. In vocal cord leukoplakia and laryngeal cancer, HPV-31 was detected in 2 of 68 patients, but all others were negative. With papilloma, on the other hand, HPV-6/11 was detected at a high rate.

Treatment for laryngeal papilloma requires surgery for the tumor and treatment for the infection. Efforts are made to use low invasive surgery that does not leave postoperative scarring. Adjuvant therapy for RLP includes cidofovir, HPV vaccination, herbal medicine, and bevacizumab. In our hospital, combination therapy with HPV quadrivalent vaccine and surgery began in 2012, and it has been able to inhibit recurrences in $70 \%$ of cases of RLP. With this treatment method, anti-HPV antibodies are induced in the laryngeal mucus with vaccination, inhibiting re-infection with HPV. RLP treatments that aim for a complete cure with elimination of HPV from the larynx and resection of the tumor should be considered.
\end{abstract}

Keywords : recurrent respiratory papillomatosis, HPV-6/11, HPV antibody, Ho:YAG Laser, Gardasil ${ }^{\circledR}$

\section{1. 喉頭疾患とHPV感染}

喉頭乳頭腫は喉頭粘膜の表面に乳頭状の腫瘍が発生する 疾患である（図 1)。従来は乳児期から発症する若年型は human papillomavirus (HPV) 感染で発症し, 成人発症型 では非ウイルス性が多いと言われていた。しかし, 我々の 先行研究では成人型の 7 割から HPV-DNAが検出され, 成 人でもウイルス性の割合が高かった。また, 再発性喉頭乳 頭腫 (recurrent laryngeal papillomatosis, RLP) は全例が HPV 陽性であった ${ }^{1)}$ 。喉頭への HPV 感染の有無を検討す るために, 声帯ポリープや声帯囊胞などの非腫瘍性疾患 44 例, 声帯白板症や上皮内癌の 29 例, 喉頭癌 35 例, 喉 頭乳頭腫 36 例に対してHPV-DNA 検査を施行した ${ }^{22}$. HPVDNA 検查は Liquid-phase hybridization 法 ${ }^{3,4)}$ と PCR 法 ${ }^{5)}$ で行った．前者はHigh-risk群 (HPV-DNA types 16, 18, $31,33,35,39,45,51,52,56,58,59,68)$ と Low-risk群 (6, 11，42，43，44）を群別に検出することができ，喉頭粘 液中の HPV-DNA 検查に用いた。後者はHPV-6, 11, 16, 18,31，33，42，52，58のタイピング検査であり，腫瘍組織 あるいは喉頭粘膜の HPV-DNA 検査に用いた。
非腫瘍性疾患では全例がHPV-DNA 除性であった。声帯 白板症の 1 例と喉頭癌の 1 例では High-risk群の HPV-31 が陽性であったが他の例では組織中 High-risk 群は㓌性で

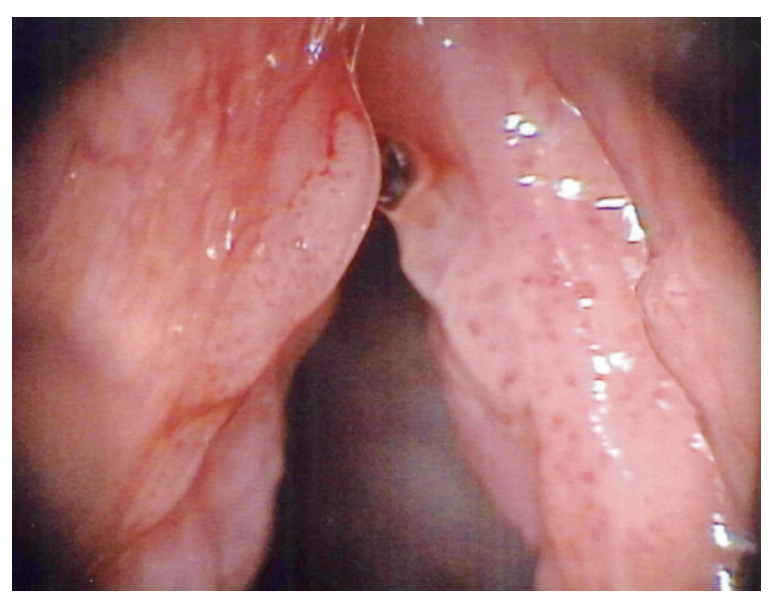

図 1 再発性喉頭乳頭腫の術中写真 
あった。一方，乳頭腫での喉頭粘液中 HPV 陽性率は $61 \%$ と高率であり, 腫瘍組織からはLow-risk群の HPV-6が $51.6 \%$, HPV-11 が $6.5 \% の$ 例で検出された ${ }^{2)}$ 。宮頸部 細胞診で異常がない 10 歳代から 60 歳代の女性群を対象に 年代別 HPV 感染率を調査した研究がある ${ }^{6)}$. 10 歳代が最 も高く HPV 陽性率は 3 割を超える。その後年齢を重ねる に従い陽性率が低下し，40歳から 50 歳代では 1 割程度に 低下する。しかし，その後再び増加し60歳代の陽性率は 2 割を超える。子宮頸部ではHPV-16/51/18などのハイリ スクタイプが $64.9 \%, H P V-6 / 11$ 他のローリスクタイプが 16.1\%検出された。すなわち子宮頸部では健常者でも様々 なタイプのHPVに感染しているが，腫瘍やがんに罹患し ていない咽頭・喉頭疾患例ではHPV 感染はなかった，咽 頭乳頭腫も一部を除けばHPV 陰性であった ${ }^{7)}$ 。一方喉頭 乳頭腫は高率にHPV $6 / 11$ が陽性であった。これらの HPV-DNA 検査結果からは子宮頸部, 咽頭, 喉頭の HPV 感染には性的接触による感染以外の要素も関与していると 考えられる。

\section{2. $H P V$ 潜在感染}

RLPは術前と同じ部位に再発することが多い，その原因 の一つが周囲の非腫瘍粘膜にHPV が潜在感染しているこ とである（図 2)。HPVは喉頭粘膜基底細胞に感染してお り粘膜表面の粘液内にHPV-DNAを放出する。放出された 喉頭粘液中 HPV-DNA が手術による粘膜欠損部位に再感染 し，乳頭腫が再発すると推測される。このことはRLPの 治療では乳頭腫に対する治療に加えて HPV 潜在感染に対 する治療が重要であることを示唆している.

\section{3. 低侵襲手術}

RLPは再発を繰り返す為に複数回の手術が必要になる。 術部粘膜の瘏痕化や癒着により重大な機能障害を来すこと も稀ではない，痏痕化や癒着を避けるためには粘膜表層に 限局した手術が要求される.

我々の施設ではホルミウムヤグレーザー (Holmium: yttrium- aluminum-garnet, Ho:YAG）を用いて粘膜表面の みを蒸散している。使用している機器はVersa Pulse ${ }^{\circledR}$
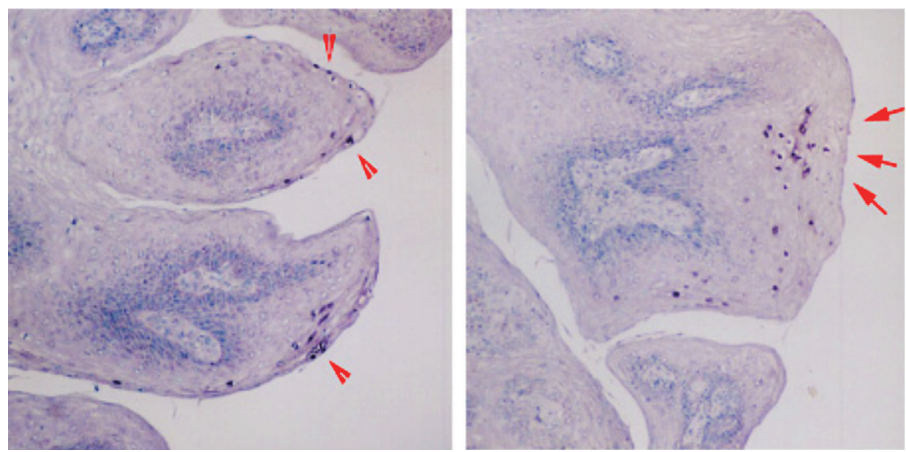

A

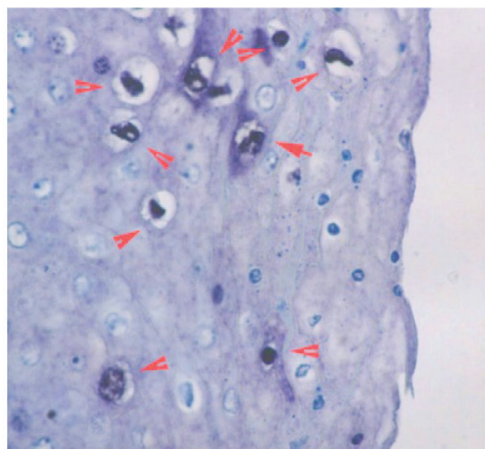

B

図 2 HPV6/11 のプローブを用いたCSA in situ hybridization法 腫瘍粘膜 $(\mathrm{A})$ に加えて非腫瘍部の粘膜 (B) からもHPV-DNAが検出された.

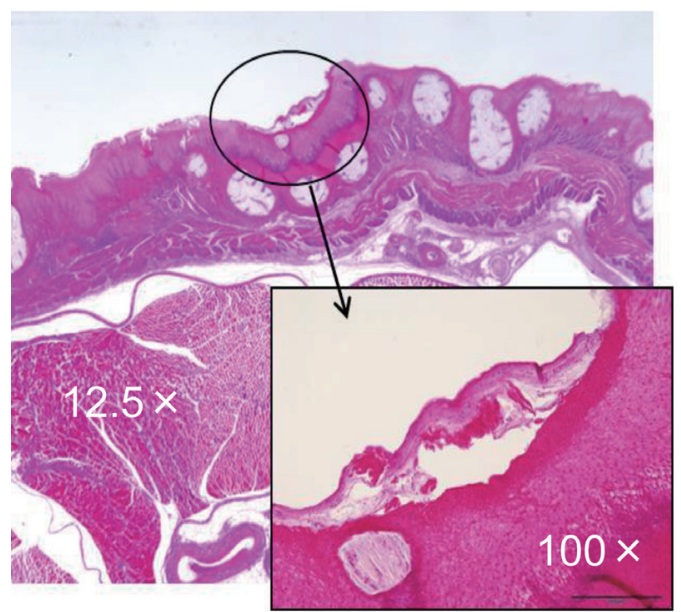

図 3 鶏肉層構造モデルを用いたホルミウムヤグレーザー蒸散実験. ファイバー先端と粘膜の間を $5 \mathrm{~mm}$ 空けて $1 \mathrm{~W}(0.2 \mathrm{j} \times 5 \mathrm{p})$ で 3 秒間照射した，表皮表層の離断や変性を認めたが皮筋，深部筋層の変性は認めなかった. 
Select ${ }^{\mathrm{TM}}$ である。鷄肉層構造モデルを作成し蒸散実験を 行った結果では, $1 \mathrm{~W}$ の出力で粘膜表面から 2 $5 \mathrm{~mm}$ の間 隔を開けて数秒間レーザー照射することで粘膜表層のみが 蒸散できることを確認した (図 3). Versa Pulse ${ }^{\circledR}$ Select $^{\mathrm{TM}}$ では喉頭微細手術用レーザー鉗子孔や喉頭ファイバース コープの処置チャンネルを通したLaser Fiberで照射する。 Fiber外径は $450 \mu \mathrm{mm}$ から $750 \mu \mathrm{mm}$ と細く繊細な先端操 作が可能である. $\mathrm{CO}_{2}$ Surgical Laserを用いる場合でも粘 膜表面を多るように蒸散することで同様の手術効果が得ら れる。

\section{4. 補助療法}

手術のみでは再発を制御できない例が多いために，様々 な補助療法が試みられてきた。表 1 は主な補助療法の一覧 である。

表 1 手術の補助療法として使用されている, あるい は期待されている薬剤

\begin{tabular}{l}
\hline \hline HPV に対する薬剤 \\
1, Cidofovir \\
2, Peginterferon alfa \\
3, HPV vaccination \\
腫瘍細胞に対する薬剤 \\
4, Indol-3-Carbinol \\
5, 漢方薬（薏茨仁, 補中益気湯) \\
6, Bevacizumab
\end{tabular}

\section{4-1. Cidofovir}

サイトメガロウイルス治療薬である。基礎研究でHPV 感染性細胞への apoptosis効果が確認されている ${ }^{8)}$. 多く の臨床報告があり CR 率は $56.25 \%$ から $82.3 \%$ と高い ${ }^{9)}$. ただ，国内外でRLPに対する適応はない．

4-2. Peginterferon alfa

体内での半減期を延長させるためにインターフェロンの タンパク分子にポリエチレングリコール (PEG : polyethylene glycol）を結合した薬剤である。6 歳の重症気道乳頭 腫例にPeginterferon alfa $1 \mu \mathrm{g} / \mathrm{kg} /$ week 皮下注射したと ころ PRを得たという報告がある ${ }^{10)}$ 。国内での使用報告は ない.

4-3. HPV vaccination

国内ではHPV-6/11/16/18の 4 価不活化ワクチンであ る Gardasil ${ }^{\circledR}$ が 9 歳以上の女性に認可されている，国外の 多くの国ではすでに数年前から HPV-6/11/16/18/31/ 33/45/52/58の 9 価ワクチンが流通している。前述した ようにRLPはHPV-6/11による感染であり 4 価ワクチン で対応できる。我々の施設では 2011 年より予防ワクチン であるGardasil ${ }^{\circledR}$ を用いた再発抑制研究を行っているので
後述する.

4-4. Indol-3-Carbinol

インドール-3-カルビノールはアブラナ科植物野菜に含 まれる成分であり，エストロゲン代謝を促進することで細 胞増殖抑制効果がある，海外では性ホルモン依存性がんの 予防目的のサプリメントとして発売されている。再発性気 道乳頭腫 (recurrent respiratory papillomatosis, RRP) 33 人を対象にした 4 年を超える長期成績の報告では, $33 \%$ の 例では腫瘍は残存するも追加手術が不要であった。また $30 \%$ の例では腫瘍増殖抑制効果が得られた ${ }^{11)}$ 。このサプ リメントは国内でも安価に手に入ることもあり他の治療法 と併用される場合が多い.

\section{$4-5$. 漢方薬}

薏药仁 (ヨクイニン) には $\mathrm{T}$ cell や B cellの活性化作用 やNK細胞や細胞障害性 T cell を活性化するなどの効果が あり，補中益気湯（ホチュウエッキトウ）はNK cellの活性 化やIFN- $\gamma$ 産生を誘導し腫瘍・感染細胞への障害がある とされている. Okubo ${ }^{12)}$ らは20人の RRP患者に漢方薬を 使用し, 経過が追えた 12 例で薬剂使用前後の比較を行っ た。漢方薬使用後では有意な手術回数減少効果や腫瘍減量 効果があったと報告した。漢方薬は国内の多くの施設で RLP例に投与されている.

4-6. Bevacizumab

ベバシズマブ $\left(\right.$ Avastin $^{\circledR}$ アバスチン $\left.{ }^{\circledR}\right)$ は血管内皮増殖 因子 (VEGF) を阻害することで腫瘍細胞の血管新生を抑 制する. RRP患者の腫瘍細胞を用いた研究でもその効果が 確認されている ${ }^{13)}$. 臨床効果についても報告があり，8歳 から 56 歳の RRP患者 5 例に投与したところ 4 例ではその 後の介入が不要であった ${ }^{14)}$. また, 小览の RRP患者 8 例 での研究では全例でPRを認めた ${ }^{15)}$ 。多施設での臨床治験 では 10 歳から 86 歳 RRP患者 8 例の中で 7 例は PR, 1 例 はCRであった ${ }^{16)}$ 。このように治療効果は期待できるが, 抗がん剂を適応外の乳頭腫に使用することは倫理的にも経 済的にも困難である。

\section{HPV予防ワクチンを用いた腫瘍再発抑制効果}

2006 年にHPV 4 価 (HPV-6/11/16/18) ワクチンである $\mathrm{Gardasil}^{\circledR}$ が $\mathrm{EU}$ や北米で承認され接種が開始された。 2 年 後の 2008 年にドイツの国内雑誌に興味ある症例が報告さ れた２歳のRLPにGardasil ${ }^{\circledR}$ を接種したところ再発が抑 制され，その後 10 か月間は手術を必要としなかった ${ }^{17)}$. その翌年にはやはりドイッで 9 回もの手術を繰り返してい た 67 歳男性RLP例に Gardasi ${ }^{\circledR}$ を接種したところ腫瘍増 殖が治まったことが報告された ${ }^{18)}$ 。これらの症例報告か ら Gardasil ${ }^{\circledR}$ を接種することで, すでに発症しているRLP の再発を抑制できる可能性が示唆された。

5-1. HPV 予防ワクチン治療の目的

RRPの多くの例で血清 HPV 抗体が陰性であり ${ }^{19)}$ ，再発 しなかった例では血清HPV 抗体価が有意に高值であっ 
表 2 性別年代別の Gardasil $^{\circledR}$ 接種後HPV 抗体価

\begin{tabular}{cccccc}
\hline \hline \multirow{2}{*}{ 性別 $^{\text {年齢 }}$} & \multicolumn{4}{c}{ HPV 抗体価平均值 $(\mathrm{mMU} / \mathrm{mL})$} \\
\cline { 3 - 6 } 女性 $^{22)}$ & $\begin{array}{c}24-34 \\
(\mathrm{n}=792)\end{array}$ & 444 & HPV-11 & HPV-16 & HPV-18 \\
女性 $^{22)}$ & $\begin{array}{c}35-45 \\
(\mathrm{n}=823)\end{array}$ & 398 & 514 & 2345 & 399 \\
男性 $^{23)}$ & $\begin{array}{c}16-24 \\
(\mathrm{n}=1092)\end{array}$ & 448 & 628 & 2134 & 326 \\
男性 $^{24)}$ & $\begin{array}{c}32-74 \\
(\mathrm{n}=12)\end{array}$ & 597.3 & 687.8 & 2404 & 402 \\
\hline
\end{tabular}

た ${ }^{20)}$ 。喉頭粘液中に抗体が存在することで周囲粘膜に潜 伏感染しているHPV-DNAが手術後の粘膜欠損部に再感染 することを阻止できるという推論が成り立つ，我々は HPV 予防ワクチンである Gardasil ${ }^{\circledR}$ を接種し喉頭粘膜に HPV 抗体を誘導した状態で再手術を行えばRLPの再発が 抑制できるという仮説を立てた。

\section{5-2. Gardasil ${ }^{\circledR}$ 接種後の獲得抗体}

Gardasil ${ }^{\circledR}$ 接種後の子宮頸部粘液と血清の HPV 抗体価を 検討した研究では両者の間に有意の関倸があった ${ }^{21)}$ 。す なわち, 局所粘液中にHPV 抗体が誘導されているか否か は血清抗体価值の高低で推測することができる，Gardasil ${ }^{\circledR}$ 接種により，女性では若年者から中年までの年代で血清抗 体価が上昇する ${ }^{22}$ ，男性でも若年者に扔いては，女性同 様に抗体価が上昇することが報告されている ${ }^{23)}$. しかし， 中年期以降の男性に対してGardasil ${ }^{\circledR}$ 接種を施行し, 血清 抗体価の変化を検証した研究はなかった。

HPV 陽性の男性RLP12 例を対象に Gardasil ${ }^{\circledR}$ 接種後の血. 清HPV 抗体価の検討を行った ${ }^{24)}$. 年齢は 32 歳から 74 歳, 平均 47.9 歳であった。 いずれの症例も複数回の手術歴が あった，全例が我々の施設で手術を受け，手術検体から HPV-DNAが検出された. Gardasil ${ }^{\circledR}$ 接種後の血清HPV 抗 体価研究 ${ }^{22,23)}$ と同様の方法で血清抗体価を測定した。測 定方法はCompetitive Luminex-based Immunoassay ${ }^{25)}$ で あった。

$\operatorname{Gardasil}^{\circledR}$ 接種直前と初回接種 7 か月後の血清抗体価を 比較した。注射前の HPV-6 抗体価は 13 と $21 \mathrm{mMU} / \mathrm{mL}$ が 各 1 例いたが, 他はすべて最小限界值である $11 \mathrm{mMU} / \mathrm{mL}$ 以下であった. HPV-11 抗体価は 1 例が $9 \mathrm{mMU} / \mathrm{mL}$ であっ たが他はすべて最小限界值である $8 \mathrm{mMU} / \mathrm{mL}$ 以下であっ た。接種後は全症例でHPV-6/11/16/18の抗体価が有意 に上昇した ${ }^{24)}$. Gardasil $^{\circledR}$ 接種前の血清抗体価は極めて低 值であった。これは過去の報告 ${ }^{22}$, 23) と一致した. HPV 感 染ではHPV-DNAが抗原として認識されにくく, 感染が粘 膜局所に留まるために血清抗体価が低いことが報告されて いる ${ }^{26)}$. 我々の研究から 26 歳以降の男性に执いても抗体
価が上昇することが明らかになり，その值は女性群 ${ }^{22)} や$ 若年男性群 ${ }^{23)}$ の抗体価と同じレベルであった（表 2).

5-3. Gardasi ${ }^{\circledR}$ 接種後の HPV-DNA 陰性化

Gardasil $^{\circledR}$ 接種を施行し抗体測定を行った 12 症例中 1 例 は癌化し放射線治療を施行した。残りの11例について $\operatorname{Gardasil}^{\circledR}$ 接種後 12 ケ月の段階での喉頭粘膜中 HPV-DNA について検討したところ 11 例中 8 例で陰性化した ${ }^{27)}$ 。そ の後Gardasil ${ }^{\circledR}$ 接種症例は 40 例を超えたが, 12 ケ月から 69 ケ月間経過を追えた 16 例を対象にHPV-DNA陰性化に ついて再度検討した ${ }^{28)}$. 16 例中 12 例 $(75 \%)$ で HPVDNA 検査が陰性化した。 Pinto ${ }^{29)}$ は中年男性を対象に HPV ワクチン接種後の唾液中 HPV 抗体を測定し, IgG抗 体を検出したことを報告した. Schwartzら ${ }^{21)}$ やPinto $ら^{29)}$ の報告から, ワクチン接種により生成された HPV 抗 体は体液中に漏出すると推測できる。本検討でワクチン接 種後にHPV-DNA 検査が陰性化した例が多かったことか ら, 喉頭粘液中にも抗体が存在する可能性が高い.

5-4. Gardasil ${ }^{\circledR}$ 接種による再発抑制効果

Gardasil ${ }^{\circledR}$ 接種中あるいは接種後に腫瘍切除術を施行し た症例の乳頭腫再発率を検討した ${ }^{28)}$. 接種終了 1 年後の 腫瘍消失率は $10 / 16$ 例（62.5\%）であった。再発した 6 例 中 5 例に対して再度手術を施行したところ 1 例ではその後 の再発を認めなかった。1 16 例中 14 例では 36 ケ月以上経 過を追えたが，11/14 例では腫瘍再発はなかった。

\section{6. 最後に}

RLPは腫瘍性疾患であるが, 感染性疾患でもある。腫瘍 に対しては発声・呼吸・噁下機能を温存する非侵襲的な手 術を行うべきである。また，再発抑制のためには抗ウイル 又治療を併用する必要がある. HPVワクチン他の効果が 期待できる抗ウイルス治療を国内でも使用できる環境整備 が求められる.

利益相反に該当する事項はない. 


\section{参 考 文 献}

1) Makiyama K, Hirai R, Matsuzaki $H$ et al. Assessment of human papilloma virus infection in adult laryngeal papilloma using a screening test. J Voice $27: 230-235$, 2013

2) Matsuzaki H, Makiyama K, Suzuki H et al : Human papillomavirus infection status of various laryngeal diseases in Japan : A comprehensive study. J Voice 31 : 504. e35-504. e40, 2017.

3) Walboomers JM, Helmerhorst TJ et al : Relation of human papillomavirus status to cervical lesions and consequences for cervical-cancer screening : a prospective study. Lancet 354 : 20-25, 1999.

4) Clavel C, Masure M, Bory JP : Human papillomavirus testing in primary screening for the detection of highgrade cervical lesions : a study of 7932 women. Br J Cancer 84 : 1616-1623, 2001.

5) Yoshikawa H, Kawana T, Kitagawa K et al : Detection and typing of multiple genital human papillomaviruses by DNA amplification with consensus primers. Jpn J Cancer Res 82: 524-531, 1991.

6) Onuki M, Matsumoto K, Satoh T et al : Human papillomavirus infections among Japanese women : age-related prevalence and type-specific risk for cervical cancer. Cancer Sci. 100 : 1312-1316, 2009.

7) Hirai R, Makiyama K, Higuti Y et al : Pharyngeal squamous cell papilloma in adult Japanese : comparison with laryngeal papilloma in clinical manifestations and HPV infection. Eur Arch Otorhinolaryngol. 269 : 22712276, 2012.

8) Andrei G, Snoeck R, Schols D et al : Induction of apoptosis by cidofovir in human papillomavirus (HPV) -positive cells. Oncol Res $12: 397-408,2000$.

9) Fusconi M, Grasso M, Greco A et al : Recurrent respiratory papillomatosis by HPV: review of the literature and update on the use of cidofovir. Acta Otolaryngol Ital 34 : 375-381, 2014.

10) Maunsell R, Bellomo-Brandão MA : Pegylated interferon for treating severe recurrent respiratory papillomatosis in a child : case report. Sao Paulo Med J 136 : 376 381, 2017.

11) Rosen CA, Bryson PC : Indole-3-carbinol for recurrent respiratory papillomatosis : long-term results. J.Voice $18: 248-253,2004$

12) Okubo K, Saito K, Fukuda H et al. Traditional Chinese medicine for treatment of laryngeal papillomatosis. J Alternat Complement Med 16 : 427-433, 2010.

13) Rahbar R, Vargas SO, Folkman J et al : Role of vascular endothelial growth factor-A in recurrent respiratory papillomatosis. Ann Otol Rhinol Laryngol 114 : 289295, 2005.

14) Mohr M, Schliemann C, Biermann C et al : Rapid response to systemic bevacizumab therapy in recurrent respiratory papillomatosis. Oncol Lett 8 : 1912 -1918, 2014.

15) Sidell DR, Nassar M, Cotton RT et al. High-dose sublesional bevacizumab (avastin) for pediatric recurrent respiratory papillomatosis. Ann Otol Rhinol Laryngol 123 : 214-215, 2014.

16) Best SR, Mohr M, Zur KB et al : Systemic bevacizumab for recurrent respiratory papillomatosis : A national survey. Laryngscope $127:$ 2225-2229, 2017.

17) Förster G, Boltze C, Seidel J : Juvenile laryngeal papillomatosis-immunisation with the polyvalent vaccine Gardasil. Laryngo Rhino Otologie 87 : 796-799, 2008.

18) Pawlita M, Gissmann L : Recurrent respiratory papillomatosis : Indication for HPV vaccination?. Dtsch Med Wochenschr 134 Suppl 2 : S100-102, 2009.

19) Maloney EM, Unger ER, Tucker RA et al : Longitudinal measures of human papillomavirus 6 and 11 viral loads and aAntibody response in children with recurrent respiratory papillomatosis. Arch Otolaryngol Head Neck Surg 132 : 711-715, 2006.

20) Chen BB, Zhao KN, Liu XS et al : The Detection and significance of human papilloma virus $11 \mathrm{~b}$ virus like particles and its serum antibody in juvenile larynx papilloma. Zhonghua Er Bi Yan Hou 38 : 417 - 420, 2003.

21) Schwarz TF, Spaczynski M, Schneider A et al : Immunogenicity and tolerability of an HPV-16/18 AS04-adjuvanted prophylactic cervical cancer vaccine in women aged 15 - 55 years. Vaccine $27: 581$ - 587 , 2009 .

22) Muñoz N, Manalastas R Jr, Pitisuttithum P et al : Safety, immunogenicity, and efficacy of quadrivalent human pPapillomavirus (types $6,11,16,18$ ) recombinant vaccine in women aged $24-45$ years : a randomised, double-blind trial. Lancet 373 : 1949 - 1957 , 2009 .

23) Hillman RJ, Giuliano AR, Palefsky JM et al : Immunogenicity of the quadrivalent human papillomavirus (type $6 / 11 / 16 / 18$ ) vaccine in males 16 to 26 years old. Clin vaccine immunol $19: 261-267,2012$.

24) Makiyama K, Hirai R, Matsuzaki H : Gardasi ${ }^{\circledR}$ vaccination for recurrent laryngeal papillomatosis in adult men-First report : Changes in HPV antibody titer, J Voice $31:$ 104-106, 2017. 
25) Dias D, Van Doren J, Schlottmann S et al : Optimization and validation of a multiplexed luminex assay to quantify antibodies to neutralizing epitopes on human papillomaviruses 6, 11, 16, and 18. Clin Diagn Lab Immunol $12: 959-969,2005$.

26) Fausch SC, Fahey LM, Da Silva DM et al : Human papillomavirus can escape immune recognition through langerhans cell phosphoinositide 3-kinase activation. J Immunol 174 : 7172-7178, 2005.

27) Hirai R, Makiyama K, Matsuzaki H et al : Gardasil vaccination for recurrent laryngeal papillomatosis in adult men. Second report: Negative conversion of HPV in laryngeal secretions. J Voice 2017 Aug 30. pii : S0892-1997 30139-X.doi : 10.1016/ j.jvoice. 2017.
07.017 .

28) Matsuzaki H, Makiyama K, Hirai R et al : Multi-year effect of human papillomavirus vaccination on recurrent respiratory papillomatosis. Laryngoscope. 2019 Apr 8. doi : 10.1002/lary.27993.

29) Pinto LA, Kemp TJ, Torres BN et al : Quadrivalent human pPapillomavirus (HPV) vaccine induces HPVspecific antibodies in the oral cavity : Results from the mid-adult male vaccine trial. J Infect Dis $214: 1276$ 1283, 2016. $\begin{aligned} \text { 別刷請求先 } & \bar{\top} 101-8309 & \text { 東京都千代田区神田駿河台 1-6 } \\ & \text { 日本大学病院耳鼻咽喉科 } & \text { 牧山 清 }\end{aligned}$ 